\title{
The Significance of Mining Infrastructural Development on South African Economy from 1980-2013:
} An Econometric Approach

\author{
Ofentse William Marutle, Olebogeng David Daw \\ North West University, South Africa \\ marutleofentse@gmail.com, David.Daw@nwu.ac.za
}

\begin{abstract}
In this present paper we investigate the relationship between mining infrastructure and economic growth in South Africa from 1980-2013. The importance of this paper is to examine if there is both short and long run significant relationship between mining infrastructure and economic growth in South Africa. The data mining was collected from South African Reserve Bank (SARB) covering the range from 1980-2013 of the paper. Both Augmented Dickey Fuller (ADF) and Phillip Perron (PP) where used for stationarity tests. Johansen Cointegration test is employed in this paper; also Vector Error Correction Model (VECM) is also employed in this paper. In the results we obtained that there is a positive significant relationship between mining infrastructure and economic growth. There is also a causal relationship between mining infrastructure and economic growth, meaning the development of mining infrastructure does promote economic growth. In conclusion the policy makers should improve private infrastructure which will equip human capital to be more useful in contributing towards knowledge and innovation. This means South African government and mining industry should priorities the development of infrastructure as component that will be sufficient towards economic development.
\end{abstract}

Keywords: Mining Infrastructure, Economic Growth, Vector Error Correction Model, Granger Causality

\section{Introduction}

The relationship between infrastructure and economic growth has been one of the most important topics to be discussed in recent years both academics and policy makers. This has also been the case for the South African economy as it is largely linked with the mining sector. However, South Africa is known to be one of the most important countries when coming to variety and quantity of minerals produced. In addition, "South Africa was built on the back of mining over 150 years and as a driving force behind the country's economy" Smit (2013). The mining sector continues to shape economic, socio political and cultural development. Furthermore, the mining industry has continued to be the third largest sector in South Africa. Many studies have proven how infrastructural development does play a major role as a factor of productivity both directly and indirectly towards economic growth. The significance of mining sector in South Africa has long been seen as of the driving force in an economy. Although, there have been numerous challenges associated with the achievement of the mining sector. The promotion of Infrastructure remains to be the challenge in South Africa, upholding the progress of economic growth to be stable in order to correct the triple challenges. In this instance, the mining sector has not been delivering more in terms of generating infrastructure more especially within the regions where mines are located. Many studies encompass the positive relationship between infrastructure and economic growth. Even though, there have been various arguments concerning the level of maximum output generated by infrastructure.

Solow (1956) in his study advocates that labor and capital are only two factors of production that enhance level of output. The theory did hold into two assumptions, firstly which was constant return to scale and diminishing marginal of returns. Romer, Mankiw and Weil (1992) in their study they further criticized Solow by endogenousing technology and include human capital in their model. They saw human capital as an important factor contributing directly to growth. The importance of this paper is to verify if the basis of Solow's growth model can be used to contribute in the economic growth of emerging countries and advance industrialized countries. Fedderke and Garlick (2008) and Kumo (2012) also concur that investment in infrastructure has the positive relationship with economic growth. However, infrastructure also contributes to economic growth when it's related to investment. Following the controversy regarding mining infrastructure, the objective of this paper is to examine the long run and short run association between mining infrastructure and economic growth. However, this paper continues to examine the casual relationship between mining infrastructure and economic growth. Specifically, the paper seeks to ascertain if mining infrastructure may possibly solve economic challenges faced by South Africa. Only selective variables 
where brought into attention such as: Mining output, mining infrastructure, employment, export and taxation. The study seek to contribute to the going debate that lack of production output in South Africa is caused by inefficiency of infrastructure, Lack of skills and demand for wages or due to escalating unemployment rate of mining sector are magnitudes towards economic problems which mining sector seeks to alleviate. The study regarding literature of mining infrastructure in South Africa and developing countries is not sufficient; therefore the study will contribute to the little current literature regarding controversy thereof. The present paper is organized in the following manner, section 1 provides with the introduction and the overview how mining infrastructure and economic growth have been performing over the years, section 2, narrate both theoretical and empirical literature review. Section 3 endow the study with data and methodology of Vector Error Correction Model, section 4 present the results and interpretations and lastly section 5 presents summary and conclusion of the study.

Overview of the study: The discovery of minerals in South Africa influenced the country's growth positively especially with regards to employment and attracting foreign investments. As Malherbe and Segal (2000) the discovery of gold and diamond in the last half of the 19th century laid foundation for transformation of South Africa more basically from agricultural economy to a modern industrialized economy. According to Fedderke and Pirouz (2002) the mining sector contribution to value added has been declining ever since the year 1970 to 1998. The industry faced numerous challenges where employment and economic growth have been declining. Rodrik (2008) also argues that South Africa has been going under remarkable transformation since democratic transition in 1994. However South African mining industry has been experiencing high rate of unemployment and low economic growth. According to Curtis(2009), the South African mining companies are enjoying generous tax treatment were they can be able to deduct 100 percent of their capital expenditure against tax, however gold mining companies do pay corporate income tax according to the formula which payments are lower to government. The gold mining companies pay corporate income tax according to the formula that keeps government payments low. When the economy is not stable companies are entitled to pay less than what is required by the South African government. The purpose of creating a formula is to create a life span for gold mining companies in South Africa after the decline in volume of gold output.

Mangondo (2006) mentions that before 1997 gold producers in South Africa were forced to sell their commodity output of gold to South African Reserve Bank and they were paid with US dollars. The Reserve bank still purchases some of the gold and they make decisions about the reserves compositions (South African Reserve Bank, 2002). The share of mining sector products in South African Merchandise exports has declined from 58\% percent in 1994 to $31.4 \%$ percent in 2003; largely the smaller growth of gold mining did contribute to the decline in mining sector. Gold exports appealed about $10.1 \%$ percent of share contribution to export basket followed by platinum group metals $9.3 \%$ percent, iron- ore $8.8 \%$ percent and coal exports $8.2 \%$ percent (Industrial development Corporate, 2013). The importance of mining industry as the relative employer to South Africa has essentially mirrored the predicament of output in past three decades (Fedderke and Pirouz, 2002).

\section{Literature Review}

Theoretical literature review: This section concentrates more on existing economic theories available. The theoretical literature is much important in this paper to confer much on historical background about developments. Many studies have brought much argument on how could emerging economies can converge with industrialized economies. Such arguments have opened interests on how government can play major role in making sure that sustainable development and economic development are reached. The theoretical underpinnings came from the classical and linear grow economists who discussed growth by formulating growth theory for development.

Robert Solow: In 1956 an American economist Robert Solow developed the study of a contribution on the theory of economic growth. He developed this study after criticizing Harrod Domar that savings is not the only variable that could expand the growth. In his study he presented the logical dynamic model with an explicit description of the process of capital accumulation in which savings and investment are being into new capital. In the Solow model, competitiveness of clearing factor markets are output produced within a year or each period are determined by available supplies capital and labor. The savings and investment are assumed to be 
exogenous, while the labor force are expected or assumed to grow at the given rate. The essential need about Solow model is that it incorporates dynamic link between savings and investment and stock of capital (Solow, 1956). According to Sorensen and Jacobsen (2005), Solow model accounts for two successive years, so the stock of capital will increase by the amount of capital minus depreciation which will be the net investment. The stock of capital is equal to the net investment after deducting depreciation. Fourie and Burger (2015) present the assumptions of which were applied by Solow growth model, firstly there is a constant return to scale and secondly diminishing marginal of returns of both labor and capital.

Endogenous growth theory: Mankiw, Romer and Weil (1992) in their study developed the model which is similar to the Solow Swan model. However in their study they added human capital and endogenous technology contrary to Solow swan model where technology was given as exogenous. The theory focuses on positive externalities and spillover effects of knowledge based economy that will lead to economic development. In the endogenous growth theory, the spillover effects are disseminated indifferent investment as the results of human capital and reduce the diminishing of returns to capital accumulation. In their controversial study, the long run growth rate of the economy does holds into policy measures. This model is also seen similar because it assumes that there is constant return to scale beside human capital which is included in the model. Mankiw, Romer and Weil (1992) saw the gap in the Solow Swan model by including human capital in their production function as a form of expanding output per worker. One of the assumptions used in the theory is that production function does not exhibit diminishing returns to scale that will lead to endogenous growth. Various rational assumptions are given such as positive spillovers where capital investment would lead to growth as economy as in the whole and improvement in technology leading to improvement in learning and various institution. In the production function, Agenor (2006) argues that an important way from Solow Swan model is the small changes in resources devoted to both physical and human capital accumulation which may lead to large changes in output per worker. Furthermore, Romer (1992) regarded technology as outcome from individual abilities to create new commodities, ideas and including human capital accordingly.

Empirical literature review: Several studies have been conducted by researchers regarding the importance of mining sector in the economy. Hajkowiez, Heyenga and Moffat (2011) presents the study in Australia examining the relationship between quantity of life indicators and gross value materials, using 71 local government areas containing mining activities of household income, housing affordability and others. Tonts, Plumber and Lawrie (2012) examined the relationship between socio economic wellbeing and resource dependence in mining towns. It is evident that these researchers have employed identical methodology but with different dataset. However, the results of the researchers were established to be identical meaning that mining sector remains to be essential in promoting economic social well-being. Although, both of the studies could not place attention into supply side of the economy by reflecting the relationship between mining employment and capital with mining production. Solomon, Katz and Lovel (2008) mention that social dimensions of mines are increasingly acknowledged as critical towards business success but yet remain to be the least of business concept of sustainable development, economy environment and society.

Akabzana and Darimani (2001) developed the study in Ghana explaining that the mining sector has attracted 3 billion of foreign direct investment and representing more than $60 \%$ of all the investments in the country. The mining industry in Ghana is known to be the leading sector by generating large investments of which the economy relies on. Amankwah and Sackey (2003) put forward their study by looking at the development in small scale of gold and diamond mining industry in Ghana and propose the strategies that can be implemented towards sustainable development within an industry and improve sustainable development within an industry. However, income generated from the mines is used to rehabilitate the existing mines and developing projects which will enhance both economic and social dimensions. Such strategies are proposed based on promoting social welfare. Fedderke and Bogetic (2002) developed the study in South Africa of infrastructure based on public investment and how does it contributes towards productivity growth.

Smit (2013) proposes that mining industry spend about 78 billion in wages and salaries, continues to be largest contributor in black economic empowerment. Kumo (2012) also made the study in South Africa about infrastructure and economic growth furthermore granger causality test was employed in a study using annual data from (1960-2009). The results were found to be that there is a causal relationship between 
economic infrastructure and investment on economic growth. Mining industry has been the backbone of emerging economies in terms of economic sphere although there have been numerous challenges affecting the social welfare of emerging economies. The results obtained from both industrialized and emerging economies ought to be different. Moncur and Jones (1999), Fedderke and Pirouz (2002), Jones (2003), Kantor (2013), Hope (2014) and Abraham (2015) have examined the study of mining sector and their challenges in South Africa. However, the study regarding literature of mining infrastructure in South Africa and developing countries is not sufficient; therefore the study will contribute to the little current literature regarding controversy thereof.

\section{Methodology}

The study adopts a Vector Error Correction Model (VECM) to estimate the importance of mining infrastructure and economic growth in South Africa. Initially the data set is used to test for stationarity using Augmented Dickey Fuller test and Phillip Perron test. Subsequently, Johansen cointegration test is employed to examine the existence of cointegration. Error Correction Model is employed to examine the short run and long run relationship, and also to examine the existence of error correction term. Diagnostic checks are performed in order to test for normality (Jaque-Bera), heteroscedasticity (White) and Serial correlation (Lagrange Multiplier). Granger causality test is employed in this paper to examine the causality between mining infrastructure and economic growth.

Empirical model estimation: The paper adopted the model developed by Solow (1956) and Romer (1992) and it was explained further by Fedderke and Pirouz (2002). The purpose of using both neoclassical and endogenous growth model is to establish the significance of mining sector as a contributor towards economic growth. It is also important for econometric evaluation for certain alternative strategies for both mining sector and government could employ in the basis of decision making. The empirical model is presented below as follows:

Where

$$
Y=K^{\alpha}(A L)^{1-\alpha}
$$

$Y$ - Output ratio

$K$ - Stock of Human capital

$A-$ Technological Progress

$L$-Labour

In order to avoid the fallacies of empirical spurious results, the description of estimated variables is given below. Some of the variables in this present paper are converted into logarithm in order to remove the trends. Such variables like employment and export where not converted into logarithm because they were collected in percentages. The above model is modified by employing the variables of Fedderke and Pirouz (2002) and was converted into estimable form as:

Where

$$
I N G D P=\beta_{0}+\beta_{1} I N G T A X+\beta_{2} E X P O R T+\beta_{3} E M P L Y+\beta_{4} I N I N F R S+\mu
$$

\footnotetext{
INGDP - Gross Domestic Product

INGTAX - General Taxation

EXPORT - Merchandise Export

EMPLY - Total Employment

ININFRS- Infrastructure
}

Data issues: The present paper employed annual time series data to examine the relationship between mining sector and economic growth in South Africa from 1980-2013. Data on all variables were collected from the electronic data source of South African Reserve Bank (SARB).The variables were transformed into stationarity since macroeconomic variables are normally carrying a random walk or being non stationary. The Augmented Dickey Fuller and Phillip Perron unit root test were employed and the test results are presented in the table below as: 
Table1: Unit root test

\begin{tabular}{|c|c|c|c|c|c|c|c|}
\hline \multirow[b]{2}{*}{$\begin{array}{l}\text { Order of } \\
\text { integration }\end{array}$} & \multirow[b]{2}{*}{ Variable } & \multicolumn{3}{|c|}{ Augmented Dickey Fuller } & \multicolumn{3}{|c|}{ Phillip Perron } \\
\hline & & Intercept & $\begin{array}{l}\text { Trend\& } \\
\text { Intercept }\end{array}$ & None & Intercept & $\begin{array}{l}\text { Trend\& } \\
\text { Intercept }\end{array}$ & None \\
\hline $2^{\text {nd }}$ dif & GDP & $-5.659 *$ & $-5.550 *$ & $-5.662^{*}$ & $-11.468^{*}$ & $-11.273^{*}$ & $-8.888^{*}$ \\
\hline $2^{\text {nd }}$ dif & INFRS & $-5.611^{*}$ & $-5.520 *$ & $-5.714^{*}$ & $-11.189^{*}$ & $-10.543^{*}$ & $-11.539 *$ \\
\hline $2^{\text {nd }}$ dif & GTAX & $-6.103^{*}$ & $-6.182^{*}$ & $-6.605^{*}$ & $-12.305^{*}$ & $-14.663^{*}$ & $-10.810^{*}$ \\
\hline $2^{\text {nd }}$ dif & EMPLY & $-5.850^{*}$ & $-5.744 *$ & $-5.949 *$ & $-6.252^{*}$ & $-6.061^{*}$ & $-6.386^{*}$ \\
\hline $2^{\text {nd }}$ dif & EXP & $-6.151^{*}$ & $-6.063^{*}$ & $-6.305^{*}$ & $-34.204^{*}$ & $-33.325^{*}$ & $-35.038^{*}$ \\
\hline
\end{tabular}

In table 1, the Augmented Dickey Fuller and Phillip Perron test where performed and the null hypothesis of both test were rejected at $1 \%$ significance level. All the variables were reported to be stationary at second differences. The importance of carrying such test is to confirm if all variables are integrated at the same order. In this case all the variables are report to be integrated at the same order of I (2).

\section{Findings}

Since it is established that all variables are integrated at the same order, Cointegration test is performed in order to determine the number of cointegrating vectors or examining the long run equilibrium relationship among variables. Cointegration means the linear combination of variables being stationary although the individual variables being non stationary. The Johansen technique of maximum likelihood is performed in this present paper to test for cointegration. The study employed the Johansen technique which requires the lag order of selection and the deterministic trend assumptions of VAR. To select the lag order under VAR, the information criteria is provided as the direction to choose the appropriate lag order. In this present paper, the maximum lag of 3 was employed to allow adjustments in the model and undertake well behaved residuals (Murwirapachena, Maredza, Choga, 2013). However, according to Liew (2004) and Mah, Petersen, Miruka and Petersen (2013) argue that it is important to focus more on Akaike Information Criteria and Final prediction Error are superior when having less than 60 observations.

Table2: Lag order of selection criteria's

\begin{tabular}{lllllll}
\hline lag & logL & LR & FPE & AIC & SC & HQ \\
\hline 0 & -232.700 & N/A & 1.948 & -14.856 & -15.085 & 14.932 \\
1 & -35.065 & 321.155 & 4.111 & -4.066 & $-5.440^{*}$ & $4.522^{*}$ \\
2 & -6.252 & $37.817^{*}$ & $3.660^{*}$ & $-3.828^{*}$ & -6.347 & 4.663
\end{tabular}

Note: asterix (*) indicates lag order selection of criterion, LR: Sequential modified LR test statistics (each test at 5\% level).FPE: Final Prediction Error. AIC: Akaike Information Criterion. SC: Schwarz Information Criterion. HQ: Hannan Quinn Information Criterion

The results in Table 2 show that most of the lag order of selection criteria (LR, FPE and AIC) depicted lag two as a best lag for our data. The agreement of lag length selection method agreed with two so the study will use lag order of two in the coming tests. The Johannsen cointegration test is conducted using lag order of 2 . The present paper has employed Johansen cointegration and do confirm if there is cointegration between the variables. In Table 3 Johansen cointegration is estimated were both trace test and maximum eigenvalue test are employed to determine number of cointegrating vectors in this paper. The results obtained show that in the case of trace test the null hypothesis of no cointegration was rejected since the test statistics of 85.082 was greater than the critical value of 69.818; hence long run relationship exists at none. Moving to another test of null hypothesis at most one the test statistics was 49.098 greater than the critical value of 47.856 so in this case we reject the null hypothesis of no cointegration, hence the long run relationship also exist at most one. Moving to another test of null hypothesis at most two the test statistics was 26.518 less than the critical value of 29.797, hence we stopped and conclude by saying there are only two cointegration relationship under trace test. 
Table3: Johansen Cointegration Test

\begin{tabular}{llllll}
\hline $\begin{array}{l}\text { Hypothesised } \\
\text { no of CE(S) }\end{array}$ & Eigen value & $\begin{array}{l}\text { Trace } \\
\text { statistics }\end{array}$ & $\begin{array}{l}\text { Critical value } \\
\mathbf{( 5 \% )}\end{array}$ & $\begin{array}{l}\text { Maximum } \\
\text { Eigen } \\
\text { statistics }\end{array}$ & $\begin{array}{l}\text { Critical value } \\
\mathbf{( 5 \% )}\end{array}$ \\
\hline None & 0.693 & $85.082^{*}$ & $69.818(0.001)$ & $36.704^{*}$ & $33.876(0.022)$ \\
At most 1 & 0.517 & $49.098^{*}$ & $47.856(0.038)$ & 22.579 & $27.584(0.192)$ \\
At most 2 & 0.477 & 26.518 & $29.797(0.113)$ & 20.100 & $21.131(0.069)$ \\
At most 3 & 0.184 & 6.418 & $15.494(0.646)$ & 6.333 & $14.26(0.570)$ \\
At most 4 & 0.002 & 0.085 & $3.841(0.770)$ & 0.085 & $3.841(0.770)$ \\
\hline
\end{tabular}

The results of maximum eigenvalue test also show that in none the maximum Eigen value statistics of 36.704 is greater than the critical value of 33.876. The null hypothesis of no cointegration is also rejected and concludes by saying there is a long run relationship at none. At most 1, 2, 3 and 4 their maximum Eigen values statistics where less than the critical values and failed to reject the null hypothesis of no cointegration. The maximum Eigen value probability was significant at none; hence the maximum Eigen test also confirms one cointegrating vector. Both the trace and maximum eigenvalue tests do confirm the long run relationship of mining sector and economic growth in South Africa. Murwirapachena, Maredza and Choga (2013) in their paper declare that, the VECM allows to distinguish both the long run and short run variables and also to establish the influence of explanatory variables towards and explanator variable. The VECM permits to separate long run and short run effect of on the model. The long run model shows the change of explanatory variables and also the behavior of economic growth in South Africa over years. Our normalized cointegration coefficients are: INGDP $P_{t}=-18.470-0.041 E X P O R T+0.014 E M P L Y-1.466 I N I N F R S=+\mu_{t}$

Table 4: Long run estimated equation

\begin{tabular}{llll}
\hline Variables & Coefficients & Std Errors & T statistics \\
\hline INGDP(-2) & 1.000 & & \\
EXPORT (-2) & 0.041 & 0.019 & $2.163^{*}$ \\
EMPLY (-2) & -0.014 & 0.011 & -1.204 \\
ININFRS (2) & 1.466 & 0.356 & $4.108^{*}$ \\
\multicolumn{2}{l}{ Note : the asterix represents significance of variables at $5 \%(*)$ and $1 \%\left(^{* *}\right)$} & \\
\hline
\end{tabular}

Table 5: Error Correction Model: INGDP

\begin{tabular}{llll}
\hline Variables & Coefficients & Std Error & T-Statistics \\
\hline D(INGDP(-1)) & 0.442 & 0.206 & 2.142 \\
D(INGDP(-2)) & -0.365 & 0.211 & -1.725 \\
D(INGTAX(-1)) & 0.146 & 0.197 & 0.741 \\
D(INGTAX(-2)) & 0.382 & 0.188 & 2.023 \\
D(EXPORT(-1)) & 0.011 & 0.078 & 0.152 \\
D(EXPORT(-2)) & -0.054 & 0.060 & -0.904 \\
D(EMPLY(-1)) & 0.002 & 0.002 & 1.311 \\
D(EMPLY(-2)) & 0.009 & 0.002 & 0.388 \\
D(ININFRS(-1)) & -0.025 & 0.155 & -0.163 \\
D(ININFRS(-2)) & -0.144 & 0.182 & -0.790 \\
COINT Eq2 & -0.323 & 0.134 & -2.412 \\
CONSTANT & -0.038 & 0.034 & -1.107 \\
Note: the asterix represents significance of variables at $5 \%\left(^{*}\right)$ and 1\% $\left(^{* *}\right)$ & \\
\hline
\end{tabular}

The long run relationship between variables as described by the equation above suggest that there is positive significant relationship between mining infrastructure and economic output in South Africa. The results obtained in a model are consistent with the study conducted by Fedderke and Garlick (2008) and Cawood (2011). However, the mining industry has been experiencing share decline of commodities together with high demand of real wages. Furthermore, the study has approved a negative insignificant relationship between 
mining employment and economic growth in South Africa. There is also positive significant relationship between export and economic growth. In the nutshell, the results confirmed that mining infrastructure is imperative when coming to economic growth towards South Africa. The coefficient of an Error Correction Model (ECT) is (-0.323) and statistically significant with a t-value of (2.412). This indicates that, the speed of adjustment is $32 \%$, implying that if there is a deviation from equilibrium then $32 \%$ of the economic growth is corrected in one year as the variables will be moving back to its trend. Furthermore, the model will go back to its normal trend with a coefficient of $32 \%$.As a result, mining infrastructure has more direct effect on economic growth in the long run and confirms the findings from the work of Perkins, Fedderke and Luiz (2005) and Kularatne (2006) who found positive significant relationship between infrastructure and economic growth.

Table 6: Diagnostic test

\begin{tabular}{llll}
\hline Test & $\mathbf{H}_{\mathbf{0}}$ : & Test statistics & P value \\
\hline Jarque Bera & There is normal distributed & 4.891 & 0.898 \\
Lagrange Multiplier & No serial correlation & 23.444 & 0.551 \\
White & No conditional Heteroscedasticity & 358.783 & 0.508 \\
\hline
\end{tabular}

In this present paper the diagnostic test was performed to confirm parameter evaluation of outcomes estimated in the model of the study. There are various methods to be employed when examining the exact outcomes and testing the fitness of the model, however, in this present paper we employed only three methods which are Jarque Bera used for normality test, Lagrange Multiplier for testing serial correlation and lastly White is employed to test for heteroscedasticity. The table above suggests that the model is normally distributed, there is no serial correlation and there is no conditional heteroscedasticity.

Table 7: Granger Causality

\begin{tabular}{lllll}
\hline Null hypothesis & Obs & Fstats & Prob & Conclusion \\
\hline ININFRS does not granger cause INGDP & 32 & 5.309 & 0.011 & Causality \\
INGDP does not granger cause ININFRS & 32 & 1.147 & 0.332 & No causality \\
EMPLY does not granger cause INGDP & 32 & 5.378 & 0.010 & Causality \\
INGDP does not granger cause EMPLY & 32 & 1.460 & 0.250 & No Causality \\
INGTAX does not granger cause INGDP & 32 & 5.449 & 0.010 & Causality \\
INGDP does not granger cause INGTAX & 32 & 0.211 & 0.810 & No causality \\
EXPORT does not granger cause INGDP & 32 & 0.267 & 0.767 & No Causality No \\
INGDP does not granger cause EXPORT & 32 & 0.696 & 0.507 & Causality \\
INGTAX does not granger cause ININFRS & 32 & 4.235 & 0.025 & Causality \\
ININFRS does not granger cause INGTAX & 32 & 0.636 & 0.537 & No causality \\
EMPLY does not granger cause ININFRS & 32 & 2.730 & 0.083 & No Causality \\
ININFRS does not granger cause EMPLY & 32 & 2.325 & 0.117 & No causality \\
EXPORT does not granger cause ININFRS & 32 & 0.378 & 0.688 & No-causality No \\
ININFRS does not granger cause EXPORT & 32 & 1.167 & 0.326 & causality \\
EMPLY does not granger cause INGTAX & 32 & 0.532 & 0.593 & No causality \\
INGTAX does not granger cause EMPLY & 32 & 1.884 & 0.171 & No causality \\
EXPORT does not granger cause INGTAX & 32 & 3.447 & 0.046 & Causality \\
INGTAX does not granger cause EXPORT & 32 & 0.259 & 0.773 & No causality \\
EXPORT does not granger cause EMPLY & 32 & 0.023 & 0.976 & No causality No \\
EMPLY does not granger cause EXPORT & 32 & 0.596 & 0.557 & causality \\
\hline
\end{tabular}

In this present paper we employ 2 lags to test for granger causality among the variables. The study presents granger causality where probabilities of variables are expected to be less than $5 \%$ then variables will granger cause each other. Granger causality test does reflect causality between Gross Domestic Product and infrastructure. The results play a major role with the study since other studies have obtained opposite results. There is sufficient evidence that infrastructure, employment and general taxation does granger cause 
economic growth. In the other hand, variables are reported to have no causal relationship. There is only one direction which runs from mining infrastructure to economic growth. Consequently, we conclude by saying there is an exact relationship between economic growth and mining infrastructure.

\section{Conclusion}

The study has examined a causal relationship between mining infrastructure and economic growth in South Africa using time series data of (1980-2013). The analysis is used to determine an impact of mining infrastructure on economic growth in South Africa using the Vector Error Correction Approach. The study has established several policy implications which were undertaken to be discussed. Firstly there is sufficient evidence suggesting that increasing mining infrastructure will expand economic growth. The current existence of infrastructure will form employment together with skills development that will constitute an increase in promoting human capital and economic growth. Furthermore, the importance of supplying skills development to employees is that they will be able to handle high value added task more efficiently and quickly. In particular, increasing infrastructure investment in human capital would endow with new ideas and more innovation. Secondly the causality of infrastructure and economic growth of the study does also support economic theory. In the study investment in infrastructure will greater allow more total output in the given input with efficient cost of input. The evidence in the study showed how infrastructure could bring growth in South Africa but more are still to be done in promoting and enforcing both public and private investments. South Africa has an adequate infrastructure but still facing triple challenges which are poverty, inequality and unemployment. Due to the rapid structural change occurred by globalization and technological change, mining employees with less education should further their studies in order to control physical capital. Acquiring expensive physical capital at the aim of containing maximum output would occur with escalating costs of producing outputs.

Thirdly, according to empirical results obtained from the study, there are more than one cointegrating vectors both in short and long run relationship in South Africa. The public sector infrastructure will only be effective in the short run and corrects the economic challenges temporarily however, including private infrastructure brings along solutions that are effective in the long run. In conclusion, the findings concerning the study are in line with current literature. The mining infrastructure has an effect on economic growth both in short and long run. In the theory of Solow both labor and capital remains to be key objective of growth. Therefore, the study recommends that policy makers should improve private infrastructure which will equip human capital to be more useful in contributing towards knowledge and innovation. This means South African mining industry should priorities the development of infrastructure as component that will be sufficient towards to economic development. Infrastructure in telecommunications, electricity, railways and other infrastructure which are directly related to production are quite imperative to create employment and increasing capacity of export promotion.

\section{References}

Abraham, V. S. (2015). The citizen: villages take on mine giant, 1 September .3

Agenor, P. R. \& Dodson, B. M. (2006). Public infrastructure and growth: new channels and policy implications, Policy Research working paper 4064, World Bank.

Akabzaa, K. \& Darimani, A. (2001). Impact of mining sector investment in Ghana: a study of the Tarkwa miningregion.https://commdev.org/userfiles/files/1466_file_Impact_20of_20Mining_20Sector_20In vestment_20in_20Ghana.pdf. 16 May 2017.

Amankwah, R. K. \& Sackey, C. A. (2003). Strategies for sustainable development of the small scale of gold and diamond mining industry of Ghana. Resource Policy, 29 (4), 131-138.

Cawood, F. T. (2011). An investigation of the potential impact of the new South African mineral and petroleum resource royal act. Journal of the South African institute of mining and metallurgy, 111, 443-453

Curtis, (2009). Mining and Tax in South Africa: cost and benefit. [Online] Availablehttp://www.curtisresearch.org.pdf.17 September 2016

Fedderke, J. \& Pirouz, F. (2002). The role of mining sector in South African economy. South African Journal Economic and Management Sciences, 5(1), 1-34 
Fedderke, J. W. \& Bogetic, L. (2002). Infrastructure and growth in South Africa: Direct and Indirect productivity impacts of 19 infrastructure measures. Working paper number 39.

Fedderke, J. \& Garlick, R. (2008). Infrastructure development and economic growth in South Africa: A review of accumulated evidence. Economic Research Southern Africa. Working paper number 12.

Fourie, C. N. \& Burger, P. (2015). How to think and reason in macroeconomics, $4^{\text {th }}$ edition. South Africa, JUTA.

Hajkowiez, S. A., Heyenga, S. \& Moffat, K. (2011). The relationship between mining and socio -economic wellbeing in Australia's region. Resource policy, 36(1), 30-38.

Hope, G. (2014). New vision for Mining. [Online] Available http://reference.sabinet.co.za.nwulib.nwu.ac.za.pdf. 23 September, 2015.

Industrial Development Corporation. South Africa. (2013). The interphase between mining and manufacturing sector in South Africa: The context. Sandton

Jones, S. (2003). Mining in the 1990s. South African Journal of Economic History, 18(2), 118-158

Kantor, B. (2013). How important is mining to the South Africa economy [Online] Availablehttp://www.voanews.com.html. 24 September 2015.

Khim, V. \& Liew, S. (2004). Which lag length selection criteria should we employ? Economics Bulletin, 3(33), 19.

Kularatne, C. (2006). Social and Economic infrastructure impacts on economic growth in South Africa. Development policy research, World Bank. [Online] Available http:file:///C:/Users/Administrator/Social_and_Economic_Infrastructure_Impacts_on_Econ.pdf. 16 May 2017

Kumo, W. L. (2012). Infrastructure investment and economic growth in South Africa: A granger causality analysis. African development bank. Working paper number 160.

Mah, G., Petersen, J. M., Miruka, C. \& Petersen, M. A. (2013). The impact of government expenditure on the Greek government debt: An econometric Analysis. Mediterranean Journal of Social Sciences, 4(3), 323330.

Mangondo, K. (2006). The economics of gold mining taxation. Pretoria: University of South Africa. (Dissertation).

Malherbe, S. \& Segal, S. (2000). A Perspective on the South African Mining Industry in the 21st Century. An independent report prepared for the chamber of mines of South Africa. Graduate School of Business and genetics analytics, University of Cape Town. Available http:/Users/ sizwe\%20phakathis\%20article\%20on\%20gold\%20mining\%20today.pdf. 16 May 2017.

Mankiw, N. G., Romer, D. \& Weil, D. N. (1992). A contribution to empirics of economic growth. The Quarterly Journal of Economics, 07(02), 407-437.

Moncur, G. \& Jones, S. (2003). The South African mining industry in the 1970s. South African Journal of Economic History, 14(2), 114-142

Murwirapachena, G., Maredza, A. \& Choga, I. (2013). The economic determinants of budget deficit in South Africa. Mediterranean Journal of Social Sciences, 4(13), 561-569.

Perkins, P., Fedderke, J. \& Luiz, J. (2005). An analysis of economic infrastructure investment in South Africa, South African Journal of Economics, 73(2), 211-228.

Rodrik, L. (2008). Understanding South Africa's Economic puzzles. Journal of Economics of Transition, 16(4), 769-797.

Romer, P. M. (1992). Two strategies of economic development: Using ideas and producing ideas. The World Bank Economic Review, 6(01), 63-91.

Smit, C. (2013). The role of Mining in the South African economy [Online] Available. http://www.sablog.kpmg.co.za.25 September 2015

Solomon, F., Katz, E. \& Lovel, R. (2008). Social dimensions of mining: Research, policy and practice challenges for the minerals industry in Australia. Resource policy, 33(3), 142-149.

Solow, R. M. (1956). A contribution to the economic growth. The Quarterly Journal of Economics, 70(1), 65-94.

Sorensen, P. B. \& Jacobsen, H. (2005). Introducing advance macroeconomics: growth and business cycle, $1^{\text {st }}$ edition, Denmark, Mc graw hall.

South African. South Africa Revenue Service. 2015. South African tax rate statistics. Pretoria

Tonts, M., Plummer, P. \& Lawrie, M. (2012). Socio economic wellbeing in Australian mining town: A comparative analysis. Journal of Rural Studies, 28(3), 288-301. 